\title{
Revue
}

\section{Métiers, effort and catches of a Mediterranean small-scale coastal fishery: The case of the Côte Bleue Marine Park}

\author{
Kevin Leleu ${ }^{a, b, c, *}$, Dominique Pelletier ${ }^{d}$, Eric Charbonnel ${ }^{c}$, Yves Letourneur ${ }^{e}$, Frédérique Alban ${ }^{f}$, \\ Frédéric Bachet $^{\mathrm{c}}$, Charles F. Boudouresque ${ }^{\mathrm{b}}$
}

\author{
a IFREMER Brest, BP 70, 29280 Plouzané, France \\ b Mediterranean Institute of Oceanography, Aix-Marseille University, CNRS/INSU, IRD, UM 110, Campus de \\ Luminy, Case 901, 13288 Marseille cedex, France \\ ${ }^{c}$ Parc Marin de la Côte Bleue, Observatoire-plage du Rouet, 31 avenue Jean Bart, BP 42, 13620 Carry-le-Rouet, \\ France \\ d IFREMER Nouvelle Calédonie, BP 2059, 98846 Nouméa cedex, New Caledonia \\ e Université de la Nouvelle Calédonie, Laboratoire LIVE, Campus de Nouville, BP R4, 98851 Nouméa cedex, New \\ Caledonia \\ ${ }^{\mathrm{f}}$ Université de Bretagne Occidentale, UEB, UMR AMURE, 12 rue du Kergoat, CS 93837, 29238 Brest cedex 3 , \\ France
}

*: Corresponding author : Kevin Leleu, email address : leleukevin@yahoo.fr

\begin{abstract}
:
The overexploitation of fishery resources has led to a major fisheries crisis. In this context, artisanal fisheries, and in particular small-scale coastal fisheries, appear as relevant alternatives for a sustainable use of coastal resources. Marine Protected Areas (MPA) are more and more used as management tools for these fisheries, as protection effects and targeted access regulations may benefit to commercial fishers. Managers and scientists need then quantitative information not only to adapt their management to the fishing activity present on their territory, but also to estimate the effects of MPA management on it. This study provides catch and effort estimates that are essential for appraising and managing the artisanal fishery in the Côte Bleue Marine Park (CBMP), a French Mediterranean MPA including two No-Take Zones of different age and size. A field protocol was defined and implemented between July 2009 and June 2010 within the CBMP. Seven métiers were identified and characterized by target species, gear type, fishing grounds and fishing periods. During the one-year studied period, 3512 fishing trips and 4645 fishing operations were performed by 30 active boats in the Côte Bleue fishing territory, amounting to $9500 \mathrm{~km}$ of immersed nets. In total, approximately 130 tons of catch were landed in the six CBMP harbors, out of which $58 \%$ depend on the three main species caught on the Côte Bleue: hake (Merluccius merluccius), gilthead seabream (Sparus aurata) and common sole (Solea solea). The presented methodology could be part of a long term monitoring requiring close collaboration with local fishers. It enables adaptive management with respect to changes in fishing pressure (from inside and outside the MPA) that may impact the environment and its resources
\end{abstract}

Keywords: Small-scale coastal fisheries ; Marine Protected Areas ; Métiers ; Fishing effort and catches 


\section{Introduction}

Artisanal fisheries - or small-scale fisheries -, are considered as potentially sustainable solutions for the exploitation of fisheries resources (Matthew, 2003; Pauly, 2006). They employ twenty-four times more fishers than large-scale fisheries, for an equivalent annual catch for human consumption (Jacquet and Pauly, 2008). Total annual fuel oil consumption by these fisheries is much lower and discards are small compared to large-scale fisheries (Kelleher, 2005; Jacquet and Pauly, 2008). Artisanal fishing fleet estimates amount to more than $80 \%$ of the worldwide fleet and of the European and Mediterranean fleets (European Commission, 2002; Guyader et al., 2007).

In Mediterranean Sea, small-scale coastal fisheries (SSCF) mainly operate on the continental shelf (0-200m depth), in areas which can be reached within a few hours from the home harbors (Farrugio and Le Corre, 1993; Colloca et al., 2004; Tzanatos et al., 2005, 2006; Duarte et al., 2009; Forcada et al., 2010; Maynou et al., 2011). Boats can be active fully or part-time of the year, and their activity is characterized by a diverse array of métiers (or fishing tactics) which can be defined as target species, fishing gears, grounds and techniques, with frequent seasonal and spatial changes to adapt to varying resource availability (Colloca et al., 2004; Forcada et al., 2010). Métiers provide a synthetic description of fishing activities which is useful for understanding the spatio-temporal patterns of effort allocation and the resulting catches (Biseau, 1998; Pelletier and Ferraris, 2000).

In $2010,88 \%$ of the 1120 active boats of the French Mediterranean fleet (excluding Corsica) were equal or smaller than $12 \mathrm{~m}$ and mostly fished within 3 nautical miles (nmi; $\sim 5.6 \mathrm{~km}$ ) from the shore. The main gears were passive ones: $64 \%$ of vessels use nets and $23 \%$ use hooks e.g. longline and fishing rod (see Leblond et al. (2012) for details). Like most fisheries worldwide, the French Mediterranean SSCF have experienced a significant decrease (53\%) in boat number since 1983 (Leonardi et al., 2009).

Published studies concerning Mediterranean SSCF mainly described fleets and their activity through the identification and the description of métiers (Colloca et al., 2004; Tzanatos et al., 2005, 2006; Duarte et al., 2009; Forcada et al., 2010). Due to the complexity of the activity, very few studies quantified effort and catch (Merino et al., 2008; Rocklin, 2010; Maynou et al., 2011), particularly in relation to Marine Protected Areas (MPA). Yet, contribution to the sustainability of adjacent fisheries is often an explicit management goal for MPAs (Claudet and Pelletier, 2004). Devising appropriate measures for this management goal 
and tracking progress toward its achievement requires quantitative data at relevant spatial and temporal scales.

The objective of this paper is to characterize the activity and the production of a SSCF located in a French Mediterranean MPA, the Côte Bleue Marine Park (CBMP), and strongly involved in the establishment and management of this specific MPA. We paid particular attention to the seasonal patterns of effort and catch, based on a year-round survey of landing, effort and fisher-related data.

In a first step, the main métiers were characterized from multivariate analyses of landing data on target species, gear used, fishing period and fishing area visited during the fishing trips. Effort and catch were then estimated for the métiers identified, consistently with the complex structure of the sampling protocol. We finally discussed the outcomes in the light of the factors influencing métiers selection and the spatial and seasonal patterns of fishing activity in the MPA.

\section{Material and methods}

\subsection{Study area}

The CBMP is an MPA located in the north-western Mediterranean Sea (Provence, France; Fig. 1). This $98.7 \mathrm{~km}^{2}$ MPA includes two No-Take Zones (NTZs), namely Carry-leRouet $\left(0.85 \mathrm{~km}^{2}\right)$ and Cap Couronne $\left(2.1 \mathrm{~km}^{2}\right)$, respectively established in 1983 and 1996 with the involvement of the local fishers' guilds (prud'homies des pêcheurs). In the rest of the CBMP, fishing regulations are similar to those enforced outside the MPA, i.e SSCF is managed through European Union regulations (e.g. maximum fishing net length), French national regulations (e.g. minimum catch size and trawl ban), and local regulations (e.g. minimum mesh size) as established by the prud'homies of Marseille and Martigues. According to French regulations, trawling is banned within 3 nautical miles from the shore (an area which includes the MPA). The CBMP holds an administrative concession for establishing artificial reefs within its boundaries; most of these were designed to prevent from illegal trawling, thereby contributing to the enforcement of the $3 \mathrm{nmi}$ trawling ban. The CBMP coordinates the management of the Natura 2000 Site of Community Importance "Côte Bleue Marine" since 2009 (FR9301999, 18928 ha; Fig. 1)

Within both the Natura 2000 site and the MPA (including the two NTZs), habitats are mainly characterized by Posidonia oceanica seagrass meadows and rocky substrata between 0 and $30 \mathrm{~m}$, sandy bottom from $30 \mathrm{~m}$ with patchy coralligenous banks between 20 and $65 \mathrm{~m}$. 
Six fishing harbors are located within the MPA: Carro, Sausset-les-Pins, Carry-le-Rouet,

111 La Redonne, Méjean and Niolon (Fig. 1). The fishing territory of Côte Bleue $\left(\sim 13 \mathrm{~km}^{2}\right)$ was

112 defined from the available spatial information (Fig. 1). Based on the data collected, it 113 encompasses more than $95 \%$ of the fishing grounds observed, and represents the relevant 114 scale for the CBMP managers.

115

\subsection{Data collection}

Register fleet data (main gear, overall length, engine power and gross tonnage of the vessels) were obtained through the registries of IFREMER and maritime office. We focused on the boats using nets as main gear. The boats either targeting urchins and coral using scuba diving or exclusively fishing sparids from long-line were not considered in this study, as their activity was marginal compared to the rest of the fishery (only three boats).

Catch and effort data were collected over a year-round survey between July 2009 and June 2010 in all harbors of the Côte Bleue area. During this period, a sample of fishers of the active boats and from the six fishing harbors (amounting to $53 \%$ of the active fleet) were interviewed approximately three times per month to collect catch and effort data relative to their most recent fishing trips (i.e. over the last 6 days). Gear, target species and fishing ground were recorded for each fishing operation of each fishing trip (a fishing trip usually encompassing several fishing operations and several distinct métiers). Over the study period and within the fishing territory of the Côte Bleue (Fig 1), 1017 fishing trips and 1667 fishing operations were described corresponding to 139 observation days (35 days per harbor on average). In addition to information on last week trips, the overall number of fishing trips realized by each fisher during the study period was recorded.

Fishing grounds were plotted on a background map by the fishers, and were subsequently entered into a Geographical Information System (ArcGIS 9.3 ${ }^{\circledR}$ ESRI software) for a total of 206 fishing spots. The habitat corresponding to each fishing spot was then determined from Astruch et al. (2011); habitat categories are sandy substrate, rocky habitat, and Posidonia oceanica meadows. Depth and distance to the shore were also used to describe fishing ground.

Landings (total weight and weight per species or group of species) were recorded for a random subsample of fishing operations representing the different métiers in each observation day. 
For $47 \%$ of the active fleet, catch and effort could not be monitored over the whole study period. Information about the gears used, the species targeted and the fishing grounds exploited during the study period were collected from several interviews with their skippers.

\subsection{Data analysis}

The number of boats and their characteristics (overall length, engine power and gross tonnage) were calculated for Carro, Sausset-les-Pins and Carry-le-Rouet. The rest of the harbors (La Redonne, Méjean and Niolon) have been merged due their small size and the small distance between them.

Main métiers were characterized from the method developed by Pelletier and Ferraris (2000), which involves a multiple correspondence analysis (MCA) followed by a Hierarchical Cluster Analysis (HCA) based on a Ward's criterion. Resulting clusters grouped fishing operations with similar gear, target species, season(s) and fishing ground(s) (see cited paper for details), and were thus considered as métiers. Fishing operations were described by four categorical variables: declared target species (7 categories), net type (3 categories), season (4 categories), and depth (3 categories; see Leleu (2012) for details). For any explanatory variable, a category was considered to significantly characterize a cluster when the frequency of the category in the cluster was significantly higher than the corresponding frequency in the overall data set (Student test, 95\% significance level).

Declared target species amounting to less than $1 \%$ of the sampled fishing operations were not considered in the analysis. In practice, this corresponded to five extra species (cuttlefish, common dentex, angler, Atlantic bonito and sardine) which were incidentally caught by the fishery (37 fishing operations i.e. $2.2 \%$ of fishing operations). Each cluster was further defined by fishing period, main habitats, depth and distance to the shore, soak time and stretched mesh size from the characteristic of the fishing operations included in the cluster.

Fishing effort was estimated consistently with the stratified two-stage sampling protocol (Cochran, 1977). Within the Côte Bleue fishing territory, the annual number of fishing trips was estimated per fishing boat and then raised at the scale of the fishing fleet. The mean number of fishing operations and mean length of net set per métier were also estimated, first per fishing boat and then raised at the fleet scale for the whole fishing period of the given métier. Estimates over fishing period had to account for the fact that métiers may be practiced by some boats only during some months of the fishing period. Thus to avoid fishing effort overestimation, elevations by métier were based on the cumulated number of 
active months by boat within the fishing period of the métier. A month was considered as active for a given boat when the boat realized at least one fishing trip during that month. Overall estimates of the number of fishing operations and of net length were obtained by summing over métiers. For each estimate, 95\% Confidence Intervals (CI) were calculated under a Gaussian approximation (for more details, see Leleu, 2012). Mean length of net set per fishing operation, mean number of métiers practiced, the total net length onboard, and the crew size per fishing trip were also calculated.

Catch per métier was estimated from non-parametric bootstrap (Efron and Tibshirani, 1993), as the number of samples did not enable to compute variance components per fishing boat and per métier. Non-parametric bootstrap is based on random sample with replacement, and does not require any assumption about data distribution. Mean catch, along with estimated variance and 95\% CI were derived from the distribution of thousand catch resamples simulated from the initial reference sample. This method was used to estimate mean catch per $100 \mathrm{~m}$ of nets, for i) all species together and for ii) target species of each métier. Total landed catch estimates were derived from mean catch estimates, based on the estimated length of set nets calculated above.

\section{Results}

\subsection{Small-scale coastal fleet structure}

Thirty boats using nets as the main fishing gear were active at least one time in two different months over the study period. Carro was the most important harbor (16 actives boats), while each of the other harbors was home to less than 7 boats (Table 1). Active boat length ranged from 5 to $16 \mathrm{~m}$ (average $9.8 \pm 2.9 \mathrm{~m}$ ), with engine power ranging from 7 to $242 \mathrm{~kW}$ (average $66.7 \pm 58.1 \mathrm{~kW}$ ) and gross registered tonnage (grt) ranging from 1.8 to 23.3 (average $7.1 \pm 5.9)$. Boat age ranged between 9 and 86 years in $2010(36.6 \pm 14.4$ years old on average; Table 1).

\subsection{Métier characterization}

Seven clusters (hereafter called métier) were identified from the multivariate analysis (Table 2). This partition explained $68 \%$ of the variance of the data set. Each cluster was strongly characterized by the declared target species or group of target species, and comprised all the fishing operations related to that species or species group. Clusters were thus named after the declared target species: "Sparids" (380 fishing operations), "European seabass" 
(153), "Mullet” (287), “Hake” (324), "Fish soup"” (122), "Rockfishes and spiny lobster" (98) 211 and "Flatfishes" (266).

Each métier used a single gear (Table 2), with the exception of "Sparids", the only 213 which also used combined nets (38\% of the fishing operations of the métier) in addition to 214 gillnet. The two métiers "European seabass" and "Flatfishes" were mainly practiced during 215 autumn-winter (during 5 and $6 \mathrm{~m}$ onths respectively; Tables 2 and 3), whereas the other 216 métiers were practiced during 5 to 9 months between March and November and particularly 217 in spring and summer (Tables 2 and 3).

With respect to fishing grounds, each métier operated in a variety of habitats, except for métiers "Hake" and "Flatfishes" which were exclusively practiced in the largest depths (> $45 \mathrm{~m}$ for respectively $100 \%$ and $95 \%$ of the fishing operations of each métier; Table 2 ) on sandy substrates (Table 3). Métiers "Sparids" and "European seabass" preferably fished at intermediate depths $(20-45 \mathrm{~m}$ for respectively $65 \%$ and $75 \%$ of the fishing operations of each métier; Table 2) above rocky habitats close to Posidonia oceanica meadows (Table 3). Métiers "Mullet" and "Fish soup" fished close to the shore in shallow waters (depth $<20 \mathrm{~m}$ for $71 \%$ and $79 \%$ of the fishing operations of each métier; Table 2), where "Posidonia oceanica" meadows are abundant. Métier "Rockfishes and spiny lobster" was found to exploit a large range of depths and distances to the shore (Tables 2 and 3). The net soak time ranged from 5 to 7 hours for métiers "Mullet" and "Fish soup" and between 14 and 18 hours for "Sparids", "European seabass", "Flatfishes" and "Hake" (Table 3). Only "Rockfishes and spiny lobster" has mean soak time longer than 24 hours (Table 3). Finally, stretched mesh size range depended on the métier, with large mesh $(\sim 91 \mathrm{~mm})$ for the métiers "Rockfishes and spiny lobster", "Sparids", "European seabass" and "Flatfishes", and small mesh ( 42 mm) for the métiers "Mullet" and "Fish soup" (Table 3). operation was realized, and 3616.2 \pm 2749.6 meters of net were set. Métiers "Flatfishes" and to a lesser extent "Hake" set the largest nets (respectively $5.8 \mathrm{~km}(95 \%$ CI [4.6; 7.1]) and $2.3 \mathrm{~km}(95 \%$ CI $[1.9 ; 2.7]))$ on average per fishing operation and caught the largest yield (respectively $38.1 \mathrm{~kg}(95 \%$ CI $[23.7 ; 57.2])$ and $60.9 \mathrm{~kg}$ (95\% CI [39.2; 88.1]); Fig. 2). Catch per $100 \mathrm{~m}$ of nets exceeded $2 \mathrm{~kg}$ for the métiers "Sparids", "European seabass" and "Hake",

\footnotetext{
1 'Fish soup' is the local name for a variety of small fishes including Scorpaenidae and Labridae, which are mixed to prepare a soup (Table 2).
} 
and were less than $1 \mathrm{~kg}$ in average for the other métiers (Fig. 2). Catch could not be accurately estimated for the métier "Rockfishes and spiny lobster" due to a too small sample size.

Each boat practiced between 1 and 6 métiers during a year, with an average of $3.6 \pm$ 1.9 métiers over one year period of time. Over the sampling year, the average number of fishing trips per boat within the fishing territory of the Côte Bleue was 128.2 (95\% CI [104.6; 151.8]), corresponding to an average of 169.5 (95\% CI [107.8; 231.3]) fishing operations per boat, and an average of 346.8 (95\% CI [221.0; 472.6]) km of nets set per boat.

Depending on the fishing period of the métiers, the length of net set per boat ranged between $32.8 \mathrm{~km}$ for "Rockfishes and spiny lobster" and $245.5 \mathrm{~km}$ for "Flatfishes", while catch per métier and per fishing boat ranged between $315 \mathrm{~kg}$ ("Fish soup", 95\% CI [113.6; $608.8]$ ) to $3477 \mathrm{~kg}$ ("Hake”, 95\% CI [1867.7; 5605.9]; Fig. 3).

Over the study period, 3512 (95\% CI [2865; 4159]) fishing trips and 4645 (95\% CI [2953; 6337]) fishing operations were realized, and more than $9500 \mathrm{~km}$ of nets $(95 \% \mathrm{CI}$ $[6056 ; 12950])$ were set by the whole fleet. With regard to catch, 130.9 tons (95\% CI [58.6; 251.4]) were landed for the 6 métiers. The métiers "Sparids" (135 active months; 16 boats), "Hake" $(98 ; 16)$, "Flatfishes" $(95 ; 18)$ and "Mullet" $(91 ; 13)$ were the most active métiers of the fleet. The métier "Fish soup" was only practiced by 10 fishing boats (equivalent to 50 active months), when "European seabass" and "Rockfishes" were practiced by 13 boats representing 65 active months.

For the whole fleet, the métier "Sparids" displayed the largest total number of fishing operations (1 340, 95\% CI [750; 1 928]), whereas "Rockfishes and spiny lobster" concerned only 249 (95\% CI [197; 301]) fishing operations (Fig. 3). The métier "Flatfishes" set the largest total net length with more than $3860 \mathrm{~km}$ (95\% CI [2 491; 5 241]), while the métiers "European seabass", "Fish soup" and "Rockfishes and spiny lobster" set less than $600 \mathrm{~km}$ of nets in average during their respective fishing period (Fig. 3).

The main target species of each métier represented between $51 \%$ and $80 \%$ of the métier catch, and overall $74 \%$ of total landed catch was made of the main targets. The total landings of métiers "Hake", "Sparids" and "Flatfishes" corresponded to $76 \%$ of the total landed catch (respectively 42.9 (95\% CI [23.0; 69.1]), 32.0 (95\% CI [14.3; 57.1]) and 25.3 tons $(95 \%$ CI $[12.9 ; 42.4]) ;$ Fig. 4$)$ and $58 \%$ of the total landed catch was made of the three species : hake (Merluccius merluccius), gilthead seabream (Sparus aurata) and common sole (Solea solea). 


\section{Discussion}

The local small-scale coastal fishery of the Côte Bleue appears to be a typical northwestern Mediterranean artisanal fishery. The boats' mean size $(<10 \mathrm{~m})$, engine power $(<75 \mathrm{~kW})$ and tonnage $(<10 \mathrm{grt})$ are consistent with those observed in the majority of French Mediterranean fisheries (Leblond et al., 2012) and of other Mediterranean countries (Colloca et al., 2004; Battaglia et al., 2010; Forcada et al., 2010). In the Côte Bleue area, the fishery relies on seven main métiers using gillnets, trammel nets and to a lesser extent combined nets. Fishing takes place in multiple fishing grounds mainly located within $3 \mathrm{nmi}$ from the shore, and corresponding to a variety of small-scale habitats (Farrugio and Le Corre, 1993; Colloca et al., 2004; Forcada et al., 2010; Leleu, 2012). Métiers are highly seasonal and catch per fishing trip remains relatively small (less than $40 \mathrm{~kg}$ per fishing operation in average with the exception of the "Hake" métier).

\subsection{Main métiers}

Given the small size of the fishery, fishing activity is quite divers over the year and between fishers. Seven main métiers were identified and characterized by a single declared target species (in all but one case), particular fishing grounds in relation to fishing depth and by well-defined seasons.

For a given métier, fishing effort is adapted to the ecology of the target species, e.g. through soak time, mesh size and net height used, and also by adjusting fishing ground selection and fishing period.

Fishing grounds correspond to target species habitat preferenda. Posidonia oceanica meadows and associated sandy substrata are visited by both "Fish soup" and "Mullets" métiers, while "Hake" and "Flatfishes" métiers fish in deeper sandy substrata. Fishing grounds for "Sparids" and "European Seabass" often correspond to a mix of the different habitats as these species are more demersal. Additional factors may interfere in fishing ground selection: seabed topography, fishers' informal agreements as well as the vicinity of the NTZ or of home harbor (Forcada et al., 2010; Leleu et al., 2012). The fine-scale spatial distribution of fishing effort in the CBMP will be addressed in a forthcoming paper.

Regarding the fishing season of a métier, it often corresponds to the period when individuals aggregate for reproduction or seasonal migration. This was the case for "European seabass", "Flatfishes" and "Sparids" or for more anecdotal métiers targeting common dentex (April - May) or cuttlefish (May - June; results not shown). For the métier "Sparids" in 
310 Sparus aurata migrate from the sea to the Berre Lagoon for the feeding period (Fig. 1); and

311 (ii) Mid-September to October for the return migration from the Berre Lagoon to the sea 312 along the shore for reproduction. Although no publ ished reference could be found, these 313 features have been long known to fishers. Fishing seasons may also depend on market 314 opportunities, especially during the summer when the large number of tourists encourages 315 fishers to propose a large panel of local species to consumers (métiers "Rockfishes", "Fish 316 soup").

The main target species identified in the present study were also found in other northwestern Mediterranean fisheries (Colloca et al., 2004; Boudouresque et al., 2005; Tzanatos et al., 2006; Cadiou et al., 2009; Battaglia et al., 2010; Forcada et al., 2010; Maynou et al., 2011), although the gears used and the fishing period depends of the natural, cultural and socio-economical characteristics of each area. For example, hakes or mullets are targeted using trammel nets in south-east of Spain or Aeolian Islands in Italy (Battaglia et al., 2010; Garcia-Rodriguez et al., 2006; Forcada et al., 2010). Moreover, species that are rarely targeted by the Côte Bleue fishery may be of major importance in other Mediterranean fisheries (common dentex or cuttlefish for example; Jabeur et al., 2000; Garcia-Rodriguez et al., 2006; Gomez et al., 2006).

\subsection{Effort and catch}

Fishers use several métiers throughout the year. Métier selection mainly depends on fishing periods, but also on other factors like recent catch and income, market demand, information and rumors about the catch of other fishers and fishers' experience (Tzanatos et al., 2006; Merino et al., 2008; Battaglia et al., 2010; Maynou et al., 2011, 2013). The use of fixed fishing gears also favors the diversity of fishing tactics and their succession throughout the year (Colloca et al., 2004; Forcada et al., 2010). Finally, the weather forecast also plays a role in day-to-day métier selection. For instance, windy conditions due to the prevailing northwestern wind (mistral) lead fishers to operate near shore in order to benefit from the coast shelter.

In contrast to métier selection, the number of fishing operations, the number of métiers practiced, and the total net length deployed per fishing trip were found to mainly depend on boat characteristics (length, power, grt) and on crew size.

Fishing takes place all over the year, as in other Mediterranean SSCF (Colloca et al., 342 2004; Tzanatos et al., 2006; Cadiou et al., 2009; Battaglia et al., 2010; Forcada et al., 2010; 343 but see Bonhomme et al., 2010; Le Diréach et al., 2010a; Rocklin, 2010). Fishing effort per 
344 métier depends on fishing period duration, the number of active months, the average catch per 345 fishing operation but also on species market price. The highest catches were obtained by 346 métiers combining high catch rates and a large number of active months. Exceptions were for 347 "European seabass", with a relatively short fishing period and a highly variable catch; and for "Flatfishes", which compensate a low catch per $100 \mathrm{~m}$ of nets by a large length of net set per fishing operation. Catch estimates displayed a high variability, illustrating variable catch rates by fishers during the fishing period. This is due to natural conditions such as water temperature, moon phases or current (Lloret et al., 2001; Darnaude et al., 2004; Stergiou et al., 2006). The majority of the catches are landed and more than $70 \%$ of the fishers declared selling $75 \%$ of their catch on harbor market. As in the majority of SSCF, fisher's family is involved in the fishing activity and selling of catch (Frangoudes and Keromnes, 2008; Leleu, 2012). In the present study, total catch could not be estimated as the fishery discards could not be assessed from the sampling protocol. Nevertheless, several onboard samples collected over the study period (Leleu, unpublished data) show average discards rates less than $10 \%$ of the total catch per fishing operation. This figure is consistent with several other studies in northwestern Mediterranean (Le Diréach and Cadiou, 2006; Tzanatos et al., 2007; Forcada et al., 2010).

Our results show that the Côte Bleue fishery mainly depends on few métiers and species, as it is the case for numbers of SSCF (Papaconstantinou and Farrugio, 2000; GarciaRodriguez et al., 2006; Gomez et al., 2006; Merino et al., 2008; Battaglia et al., 2010; Maynou et al., 2011; Colloca et al., 2013). This illustrates the vulnerability of these fisheries facing possible changes in resources. In the CBMP, the mean length of nets for the métier "Flatfishes" has been multiplied by 2.3 since 1988 (Bachet F., pers. comm.). Net lengths over $10 \mathrm{~km}$ per fishing operation are now commonly used (with a maximum observed of $14 \mathrm{~km}$ ), which exceeds the lengths authorized by European regulations (Council Regulation $\mathrm{n}^{\circ} 1967 / 2006$, i.e. $4000 \mathrm{~m}$ per boat, plus $1000 \mathrm{~m}$ per extra fisher with a maximum of $6000 \mathrm{~m}$ ). The "Flatfishes" métier exhibits the lowest catch rates observed in this study. All fishers reported either a decrease (35\% of them) or stability $(65 \%)$ in Solea solea catch over the last 372 decade, whereas $64 \%$ of fishers declared having increased their net length (Leleu, 2012). 373 Solea solea stocks could be certainly considered as overexploited in the Côte Bleue area as it 374 is probably the case in the whole Mediterranean Sea (de Séligny and Grainger, 2010), but environmental factors, e.g. continental Particular Organic Matter (POM) episodic inputs via river floods, may also partly explain the availability of this resource (Darnaude et al., 2004). 
Such changes will inevitably induce an evolution of fishing activities in the near future, with effort shifting to other métiers and associated consequences on resources.

Given this evolution, the potential of the CBMP NTZ to contribute to (partially) replenish exploited resources may be key in the future. Several studies provide scientific evidence for biomass export from CBMP's NTZs for some target species of the métiers "Sparids" and "European seabass" (Diplodus spp.), but also "Mullets" (Mullus surmuletus), "Fish soup" (Scorpaena spp., Symphodus spp.) and "Rockfishes" (Scorpaena spp., Labrus spp.) (Goñi et al., 2008; Harmelin-Vivien et al., 2008; Le Diréach et al., 2010b; Leleu et al., 2012). If the effect of NTZs on the flatfishes was not studied, it may be positive, particularly in the reserve of Cap Couronne which includes wide areas of sandy substrate beyond $\sim 30 \mathrm{~m}$ depth (Charbonnel, pers. comm). In the future, the vicinity of the recently created Calanques National Park may also play a role in the evolution of exploited resources.

It was difficult to achieve a comparison between effort and catches of different northwestern Mediterranean SSCF because papers report distinct indicators, and because this information was rarely displayed in the literature. To achieve such a comparison, it would be necessary to compute similar indicators for each fishery, especially in terms of catches. Such a study would provide valuable information on the biology of exploited species and associated stocks, but also on the dependence of the fisheries upon ecological features. For this last point, the production of the Métier-Sustainability-Index (MSI25) by Tzanatos et al. (2013) is an interesting avenue.

\subsection{An adapted sampling protocol}

Through an extensive year-round survey of this SSCF, we could document fishing practices and provide quantitative estimates of effort and catch, together with precision estimates. This was made possible through a sampling protocol adapted to two features that are common to most temperate small-scale fisheries: i) multiple target species and several métiers, and ii) a strong seasonality of fishing activities with fishers practicing a succession of métiers along the year depending on changes in resource distribution and availability.

These results may be useful for designing monitoring protocols for SSCF in a context where coastal fishing activities are likely to be impacted by environmental changes, changes in management regulations and changes in pressures due to other human activities (including larger fisheries) in the coastal area. 


\section{5. Acknowledgments}

412 The authors would like to thank the prud'homies des pêcheurs of Marseille and 413 Martigues for their collaboration, as well as all the fishers who accepted to share the 414 information on their activity. They are grateful to the team of the Côte Bleue Marine Park for 415 their precious assistance during the field survey. This study was part of two multidisciplinary 416 research projects on governance and performance of MPAs, namely GAIUS (http://www.crh417 sete.org/projets/fiche_gaius.pdf) and PAMPA (http://wwz.ifremer.fr/pampa). It was partly 418 funded by the research project GAIUS. Finally the authors also thank the two anonymous 419 reviewers and the editor for their useful comments on the submitted manuscript. 
Cochran, G. C., 1977. Sampling Techniques. Wiley \& Sons, NY, USA. PMCB \& GIS Posidonie Publishers, Marseille, France. Islands, Italy). Fish. Res. 102. 87-97. its impact on stock assessments. Aquat. Living Resour. 11, 119-136. of Marine Ecosystems. Springer, Netherlands, pp. 29-52. (northwest Mediterranean Sea): a success story? ICES J. Mar. Sci. 66, 41-49. 138.

Astruch, P., Goujard, A., Charbonnel, E., Rogeau, E., Rouanet, E., Bachet, F., Bricout, R., Bonhomme, D., Antonioli, A., Bretton, O., Monin, M., Harmelin, J.G., Sartoretto, S., Chevaldonne, P., Zibrowius, H., Verlaque, M., 2011. Inventaires biologiques et analyse écologique de l'existant, Natura 2000 en mer, Lot n¹2 'Côte Bleue Marine' FR 9301999.

Battaglia, P., Romeo, T., Consoli, P., Scotti, G., Andaloro, F., 2010. Characterization of the artisanal fishery and its socio-economic aspects in the central Mediterranean Sea (Aeolian

Biseau, A., 1998. Definition of a directed fishing effort in a mixed-species trawl fishery, and

Bonhomme, P., Roubaud, V., Rogeau, E., Goujard, A., Le Diréach, L., Bonhomme, D., Boudouresque, C.F., 2010. Suivi de l'effort de pêche professionnelle dans les eaux du Parc national de Port-Cros. Année 2009. GIS Posidonie Publishers, Marseille, France.

Boudouresque, C.F., Cadiou, G., Diréach, L., 2005. Marine protected areas: a tool for coastal areas management, in: Levner, E., Linkov, I., Proth, J.-M. (Eds.), Strategic Management

Cadiou, G., Boudouresque, C.F., Bonhomme, P., Le Diréach, L., 2009. The management of artisanal fishing within the Marine Protected Area of the Port-Cros National Park

Claudet, J., Pelletier, D., 2004. Marine protected areas and artificial reefs: a review of the interactions between management and scientific studies. Aquat. Living Resour. 17, 129 - 
Colloca, F., Crespi, V., Cerasi, S., Coppola, S.R., 2004. S tructure and evolution of the artisanal fishery in a southern Italian coastal area. Fish. Res. 69, 359-369.

Colloca, F., Cardinale, M., Maynou, F., Giannoulaki, M., Scarcella, G., Jenko, K., Bellido, J., Fiorentino, F., 2013. Rebuilding Mediterranean fisheries: a new paradigm for ecological sustainability. Fish Fish 14, 84-109.

Darnaude, A., Salen-Picard, C., Polunin, N.C., Harmelin-Vivien, M., 2004. Trophodynamic linkage between river runoff and coastal fishery yield elucidated by stable isotope data in the Gulf of Lions (NW Mediterranean). Oecologia 138, 325-332.

de Séligny, J., Grainger, R., 2010. The State of World Fisheries and Aquaculture 2010. FAO, Rome.

Duarte, R., Azevedo, M., Afonso-Dias, M., 2009. Segmentation and fishery characteristics of the mixed-species multi-gear Portuguese fleet. ICES J. Mar. Sci 66, 594-606.

Efron, B., Tibshirani, R., 1993. An Introduction to the Bootstrap. Chapman and Hall, New York.

European Commission, 2002. 535 final. Communication from the Commission to the Council and the European Parliament laying down a Community Action Plan for the conservation and sustainable exploitation of fisheries resources in the Mediterranean Sea under the Common Fisheries. Commission of the European Communities, Brussels.

Farrugio, H., Le Corre, G., 1993. A sampling strategy and methodology for assessment and monitoring of Mediterranean small-scale fisheries. Sci. Mar. 57, 131-137.

Frangoudes, K., Keromnes, E., 2008. Women in artisanal Fisheries in Brittany, France. Dev. $51,265-270$.

Forcada, A., Valle, C., Sánchez-Lizaso, J.L., Bayle-Sempere, J.T., Corsi, F., 2010. S tructure and spatio-temporal dynamics of artisanal fisheries around a Mediterranean marine protected area. ICES J. Mar. Sci. 67, 191-203. 
Garcia-Rodriguez, M., Fernandez, A.M., Esteban, A., 2006. Characterisation, analysis and catch rates of the small-scale fisheries of the Alicante Gulf (SE Spain) over a 10 years time series. Fish. Res. 77, 226-238.

Gomez, S., Lloret, J., Riera, V., 2006. The decline of the Artisanal Fisheries in Mediterranean Coastal Areas: the Case of Cap de Creus (Cape Creus). Coast. Manage. 34, 217-232.

Goñi, R., Adlerstein, S., Alavrez-Berastegui, D., Forcada, A., Reñones, O., Criquet, G., Polti, S., Cadiou, G., Valle, C., Lenfant, P., Bonhomme, P., Pérez-Ruzafa, A., Sánchez-Lizaso, J.L., García-Charton, J.A., Bernard, G., Stelzenmüller, V., Planes, S., 2008. Spillover from six western Mediterranean Marine Protected Areas: evidence from artisanal fisheries. Mar. Eco. Prog. Ser. 366, 159-174.

500

Guyader, O., Berthou, P., Koustikopoulos, C., Alban, F., Demaneche, S., Gaspar, M., 502 Eschbaum, R., Fahy, E., Tully, O., Reynal, L., Albert, A., 2007. S mall-Scale Coastal 503 Fisheries in Europe. Final report of the contract no. FISH/2005/10. http://archimer.ifremer.fr/doc/2007/rapport-6348.pdf

Harmelin-Vivien, M., Le Diréach, L., Bayle-Sempere, J., Charbonnel, E., García-Charton, J.A., Ody, D., Pérez-Ruzafa, A., Reñones, O., Sánchez-Jerez, P., Valle, C., 2008.

Jabeur, C., Gobert, B., Missaoui, H., 2000. Typologie de la flottille de pêche côtière dans le Gradients of abundance and biomass across reserve boundaries in six Mediterranean marine protected areas: Evidence of fish spillover? Biol. Conserv. 141,1829-1839.

Kelleher, K., 2005. Discards in the world's marine fisheries: an update, vol. 470. FAO, Rome. 
Le Diréach, L., Cadiou, G., 2006. Suivi de l'effort de pêche professionnelle dans la réserve naturelle de Scandola (Corse). Données 2006. GIS Posidonie Publishers, Marseille, France

Le Diréach, L., Bonhomme, P., Boudouresque, C.F., Cadiou, G., 2010a. Fishing effort and catches in the marine protected area of Scandola and adjacent areas (Corsica, Mediterranean). Rapp. Comm. Int'1 Explor. Mer Mediterr. 39, 770.

Le Diréach, L., Astruch, P., Charbonnel, E., Bonhomme, D., Bachet F, Daniel, B., 2010b. Suivi des peuplements de poissons de la Réserve Marine du Cap Couronne (Parc Marin de la Côte Bleue) - Bilan 1995-2007. PMCB \& GIS Posidonie Publishers, Marseille, France.

Leonardi S., Leblond, E., Le Blond S., Marchal P., 2009. Evolution et répartition de la capacité physique et de l'effort de pêche des navires français. Estimation de l'adéquation de la capacité utilisée et des possibilités de pêche. $\underline{\text { http://archimer.ifremer.fr/doc/00001/11213/ }}$

Leblond, E., Daures, F., Berthou, P., Merrien, C., Pitel-Roudaut, M., Le Grand, C., Demaneche, S., Jezequel, M., Bodere, E., Le Blond, S., Macher, C., 2012. Synthèse des flottilles de pêche 2010. Flotte de Mer du Nord - Manche - Atlantique. Flotte de Méditerranée. http://archimer.ifremer.fr/doc/00117/22797/20601.pdf

Leleu, K., (PhD Thesis ) 2012. Suivi et évaluation de la pêche professionnelle au sein d'une Aire Marine Protégée : protocoles d'enquêtes et indicateurs de pression et d'impact. Application au Parc Marin de la Côte Bleue., Université Aix Marseille, France http://archimer.ifremer.fr/doc/00100/21103/18729.pdf

Leleu, K., Alban, F., Pelletier, D., Charbonnel, E., Letourneur, Y., Boudouresque, C.F., 2012. Fishers' perceptions as indicators of the performance of Marine Protected Areas (MPAs). Mar. Policy. 36, 414-422. 
Lloret, J., Lleonart, J., Solé, I., Fromentin, J.-M., 2001. F luctuations of landings and environmental conditions in the north-western Mediterranean Sea. Fish. Ocean. 10, 3350.

Matthew, S., 2003. S mall-scale fisheries perspectives on an ecosystem-based approach to fisheries management. In: FAO (Ed.), Responsible fisheries in the marine ecosystem. FAO, Rome, pp. 47-64.

Maynou, F., Recasens, L., Lombarte, A., 2011. Fishing tactics dynamics of a Mediterranean small-scale coastal fishery. Aquat. Living Resour. 24, 149.

Maynou, F., Morales-Nin, B., Cabanellas-Reboredo, M., Palmer, M., García, E., Grau, A.M., 2013. Small-scale fishery in the Balearic Islands (W Mediterranean): A socio-economic approach. Fish. Res. 139, 11-17.

Merino, G., Morales-Nin, B., Maynou, F., Grau, A.M., 2008. Assessment and bioeconomic analysis of the Majorca (NW Mediterranean) trammel net fishery. Aquat. Living Resour. $21,99-107$.

Papaconstantinou, C., Farrugio, H., 2000. Fisheries in the Mediterranean. Mediterr. Mar. Sci. $1,5-18$.

Pauly, D., 2006. Major trends in small-scale marine fisheries, with emphasis on developing countries, and some implications for the social sciences. Marit. Stud. 4, 7-22.

Pelletier, D., Ferraris, J., 2000. A multivariate approach for defining fishing tactics from commercial catch and effort data. Can. J. Fish. Aquat. Sci. 57, 51-65.

Rocklin, D., (PhD Thesis) 2010. Des modèles et des indicateurs pour évaluer la performance d'aires marines protégées pour la gestion des zones côtières. Application à la Réserve Naturelle des Bouches de Bonifacio (Corse). Université de Montpellier 2, F rance. http://www.biu-montpellier.fr/florabium/jsp/nnt.jsp?nnt=2010MON20145. 
Stergiou, K.I., Moutopoulos, D.K., Soriguer, M.C., Puente, E., Lino, P.G., Zabala, C., Monteiro, P., Errazkin, L.A., Erzini, K., 2006. Trammel net catch species composition, catch rates and métiers in southern European waters: a multivariate approach. Fish. Res. 79, 170-182.

Tzanatos, E., Dimitriou, E., Katselis, G., Georgiadis, M., Koutsikopoulos, C., 2005. Composition, temporal dynamics and regional characteristics of small-scale fisheries in Greece. Fish. Res. 73, 147-158.

Tzanatos, E., Somarakis, S., Tserpes, G., Koutsikopoulos, C., 2006. Identifying and classifying small-scale fisheries métiers in the Mediterranean: a case study in the 596

Tzanatos, E., Somarakis, S., Tserpes, G., Koutsikopoulos, C., 2007. Discarding practices in a 598 Patraikos Gulf, Greece. Fish. Res. 81, 158-168.

600

Tzanatos, E., Castro, J., Forcada, A., Matić-Skoko, S., Gaspar, M., Koutsikopoulos, C., 2013. 602 A Métier-Sustainability-Index (MSI25) to evaluate fisheries components: assessment of 603 cases from data-poor fisheries from southern Europe. ICES J. Mar. Sci 70, 78-98. 


\section{Figure captions}

606

607 Fig. 1. Study area: The Côte Bleue Marine Park (CBMP; dotted area), its two no-take zones 608 (NTZ; dark grey areas) and the limit of the Natura 2000 site (crossed line). The hatched area 609 represents the fishing territory of the Côte Bleue small-scale coastal fishery.

610

611 Fig. 2. Estimations and 95\% confidence intervals of the net length (left), the catch landed per $612100 \mathrm{~m}$ of nets (middle) and the total landed catch (right) per fishing operation and per métier. 613 Catch was not estimated for the métier "Rockfishes and spiny lobster" due to low sample size. 614

615 Fig. 3. Estimations and 95\% confidence intervals of the number of fishing operations (left), 616 net length (middle), and the total landed catch (right) per boat and fleet for each métier. Catch 617 was not estimated for the métier "Rockfishes and spiny lobster" due to low sample size.

619 Fig. 4. Estimation and 95\% confidence interval of the landed catches (tons) per target species and per métier (except Rockfishes and spiny lobster) over the studied year.

Table 1. Number of boats using nets (registered and active at least two months during the study period) and fleet characteristics (range, mean and standard deviation (sd) of the overall

624 length $(\mathrm{m})$, of the engine power $(\mathrm{kW})$, of the gross tonnage (grt) and of the year of 625 construction) for each of the CBMP harbors.

Table 2. Characterization of the métiers obtained from the classification of fishing operations based on the four categorical variables.

Table 3. Description of the métiers according to the characteristics of the fishing operations

631 included in each cluster. Each métier is described through its target species, its fishing period, 632 the habitat visited (P, Posidonia oceanica meadow; R, rocky substrata; S, sandy substrata), the 633 range of fishing depth, distance from the shore, net mesh size (stretched), height when fishing, 634 and soak time. Fishing period of each métier corresponds to the grey shading: no shading: less 635 than $5 \%$ of the whole fishing operations observed during the specific month; light grey 636 shading: between 5 and $10 \%$; dark grey shading: more than $10 \%$. 


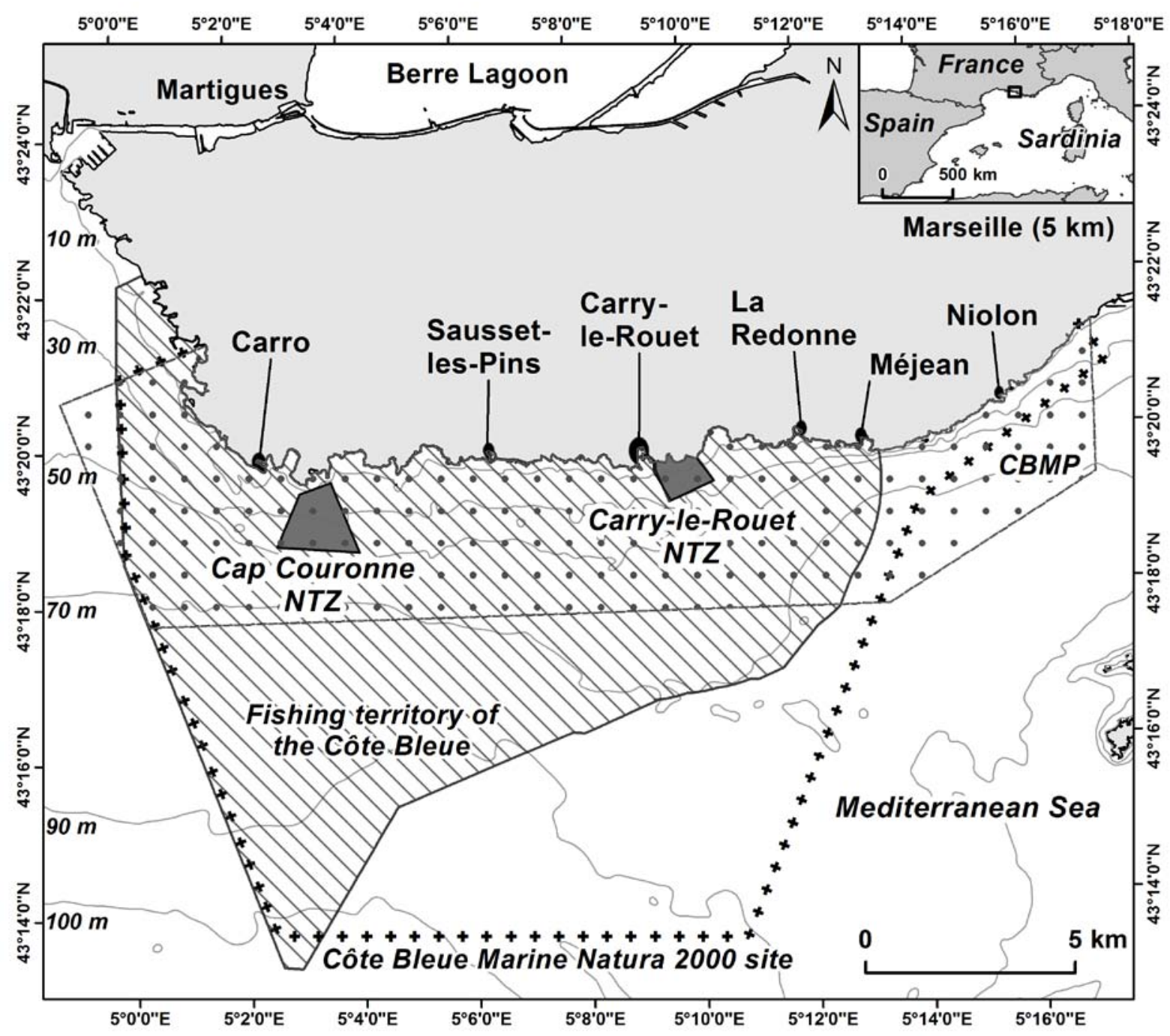

637

638

639

640

Fig. 1. Study area: The Côte Bleue Marine Park (CBMP; dotted area), its two no-take zones (NTZ; dark grey areas) and the limit of the Natura 2000 site (crossed line). The hatched area represents the fishing territory of the Côte Bleue small-scale coastal fishery. 


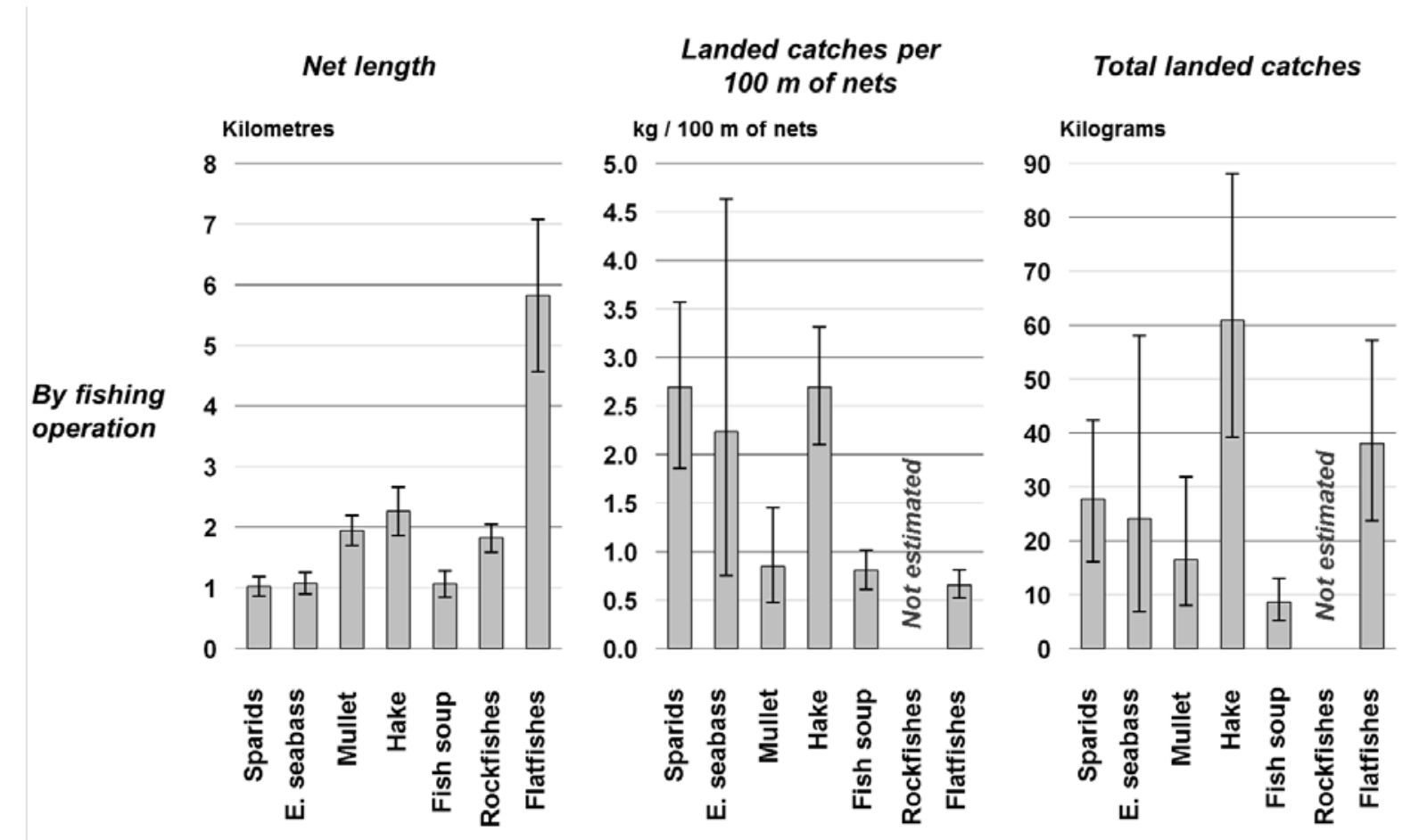

642 Fig. 2. Estimations and 95\% confidence intervals of the net length (left), the catch landed per $643100 \mathrm{~m}$ of nets (middle) and the total landed catch (right) per fishing operation and per métier. 644 Catch was not estimated for the métier "Rockfishes and spiny lobster" due to low sample size. 


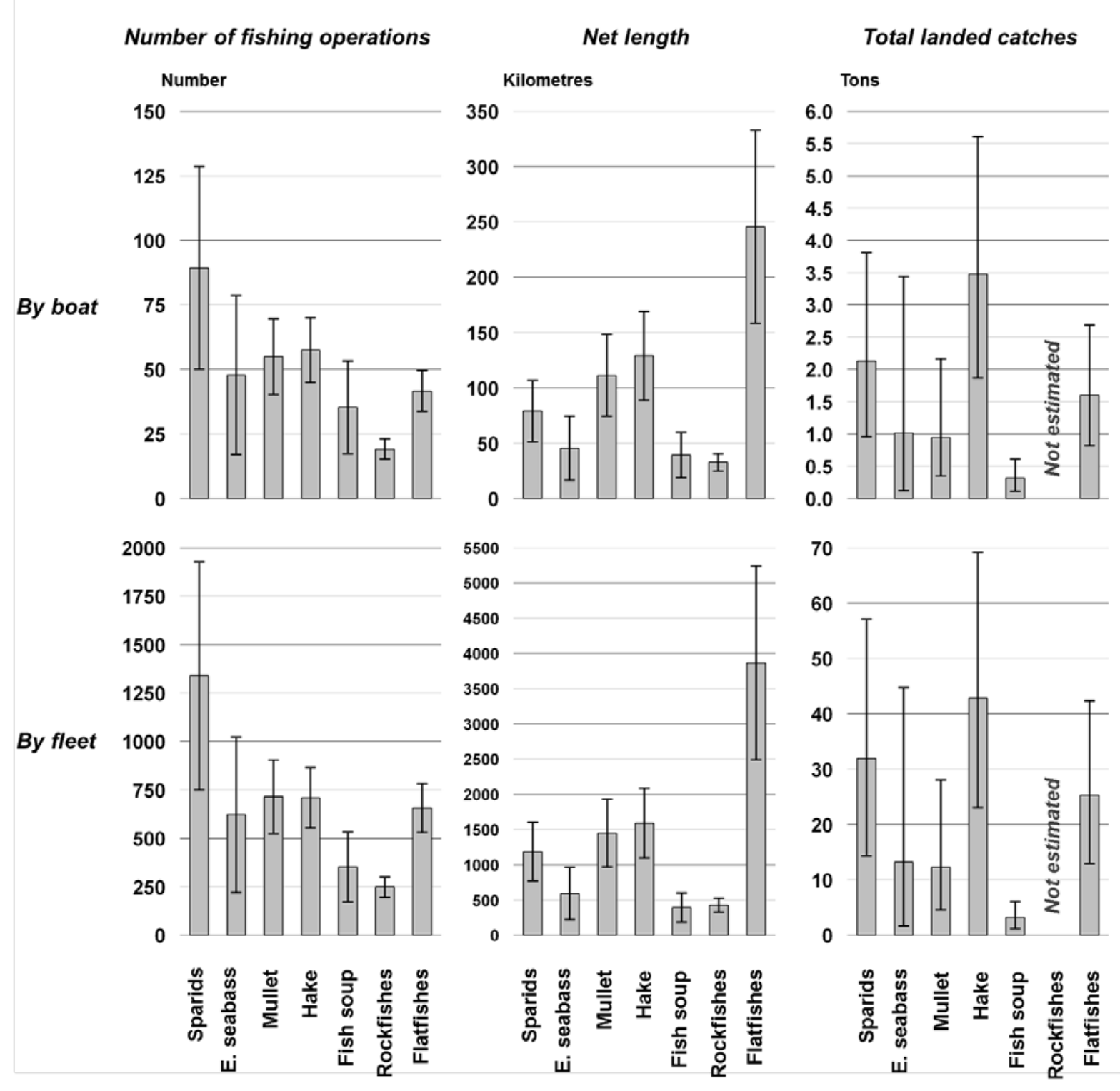

Fig. 3. Estimations and 95\% confidence intervals of the number of fishing operations (left), 647 net length (middle), and the total landed catch (right) per boat and fleet for each métier. Catch 648 was not estimated for the métier "Rockfishes and spiny lobster" due to low sample size. 

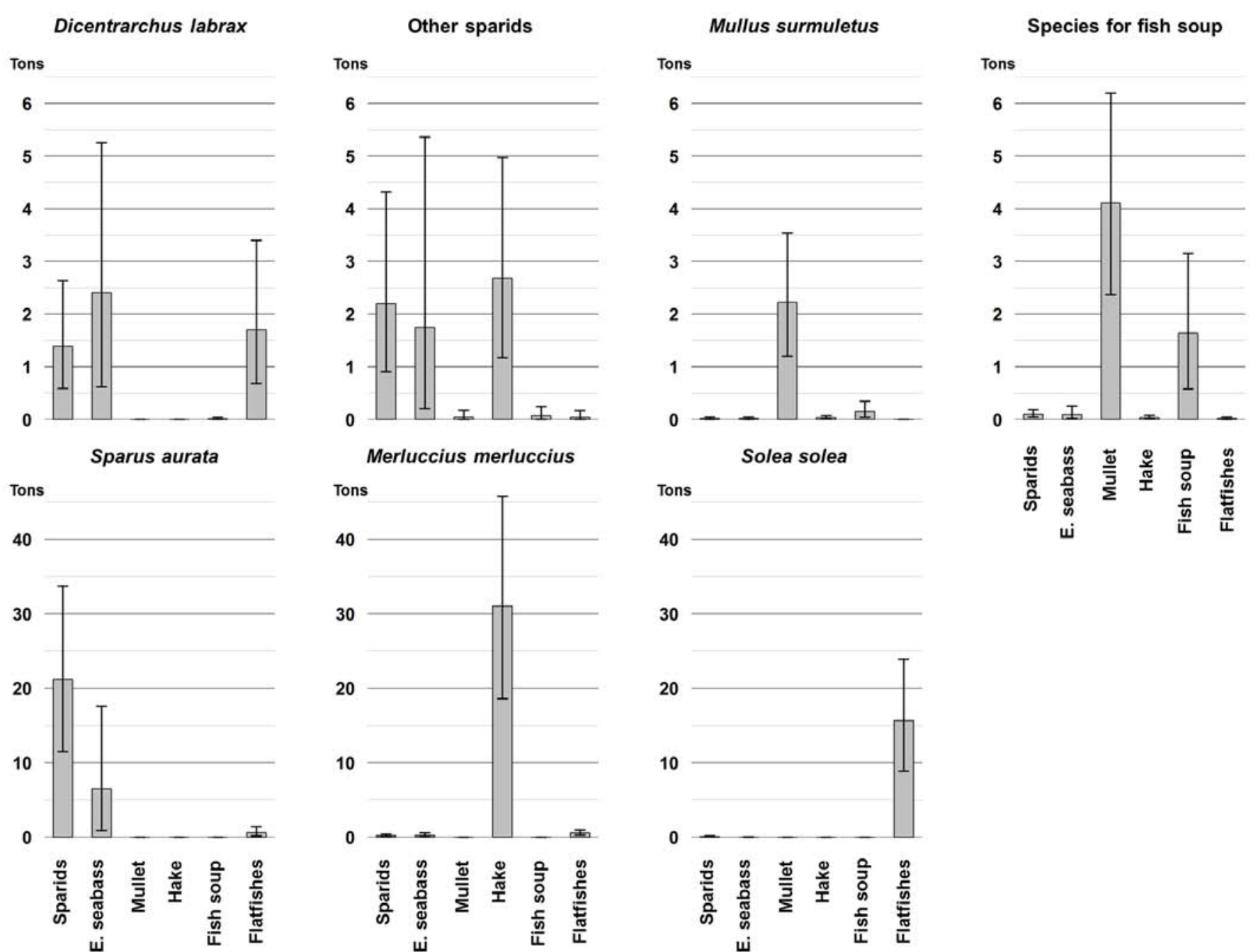

Solea solea

Tons

40

แ่

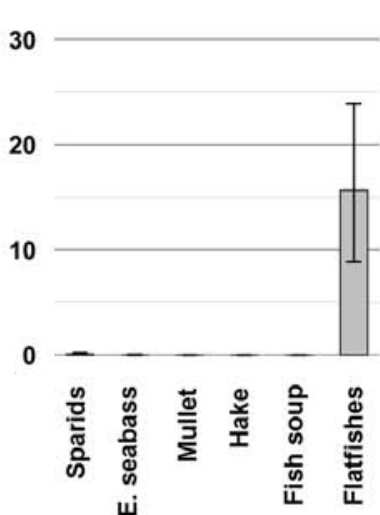

Fig. 4. Estimation and $95 \%$ confidence interval of the landed catches (tons) per target species and per métier (except Rockfishes and spiny 651 lobster) over the studied year. 
Table 1. Number of boats using nets (registered and active at least two months during the study period) and fleet characteristics (range, mean and standard deviation $(\mathrm{sd})$ of the overall length $(\mathrm{m})$, of the engine power $(\mathrm{kW})$, of the gross tonnage (grt) and of the year of construction) for each of the CBMP harbors.

\begin{tabular}{|c|c|c|c|c|c|}
\hline \multirow[t]{3}{*}{ Harbors } & \multirow{3}{*}{$\begin{array}{l}\text { Number of } \\
\text { active } \\
\text { boats using } \\
\text { nets }\end{array}$} & \multicolumn{4}{|c|}{ Characteristics of active boats using nets } \\
\hline & & $\begin{array}{l}\text { Overall length } \\
\text { (m) }\end{array}$ & $\begin{array}{l}\text { Engine power } \\
(\mathrm{kW})\end{array}$ & $\begin{array}{l}\text { Gross tonnage } \\
\text { (grt) }\end{array}$ & $\begin{array}{l}\text { Year of } \\
\text { construction }\end{array}$ \\
\hline & & $\begin{array}{l}\text { Range } \\
(\text { mean } \pm \text { sd) }\end{array}$ & $\begin{array}{l}\text { Range } \\
(\text { mean } \pm \text { sd) }\end{array}$ & $\begin{array}{l}\text { Range } \\
\text { (mean } \pm \text { sd) }\end{array}$ & $\begin{array}{l}\text { Range } \\
(\text { mean } \pm \text { sd) }\end{array}$ \\
\hline Carro & 16 & $\begin{array}{l}5.5-16.2 \\
(10.7 \pm 3.3)\end{array}$ & $\begin{array}{l}6.7-241.7 \\
(79.5 \pm 64.5)\end{array}$ & $\begin{array}{l}1.9-23.3 \\
(9.4 \pm 6.9)\end{array}$ & $\begin{array}{l}1958-1994 \\
(1976 \pm 9.2)\end{array}$ \\
\hline Sausset-les-Pins & 5 & $\begin{array}{l}6.9-12.5 \\
(9.3 \pm 2.4)\end{array}$ & $\begin{array}{l}16.4-56.0 \\
(35.8 \pm 14.3)\end{array}$ & $\begin{array}{l}1.8-9.9 \\
(4.9 \pm 3.5)\end{array}$ & $\begin{array}{l}1924-1989 \\
(1965 \pm 25.2)\end{array}$ \\
\hline Carry-le-Rouet & 2 & $\begin{array}{l}11.2-12.0 \\
(11.6 \pm 0.6)\end{array}$ & $\begin{array}{l}83.6-119.4 \\
(101.5 \pm 25.3)\end{array}$ & $\begin{array}{l}7.0-9.3 \\
(8.2 \pm 1.6)\end{array}$ & $\begin{array}{l}1973-1981 \\
(1979 \pm 5.7)\end{array}$ \\
\hline $\begin{array}{l}\text { La Redonne - } \\
\text { Méjean - Niolon }\end{array}$ & 7 & $\begin{array}{l}7.0-9.6 \\
(7.8 \pm 1.0)\end{array}$ & $\begin{array}{l}16.4-186.5 \\
(49.8 \pm 60.9)\end{array}$ & $\begin{array}{l}2.2-5.5 \\
(3.2 \pm 1.2)\end{array}$ & $\begin{array}{l}1958-2011 \\
(1971 \pm 16.4)\end{array}$ \\
\hline
\end{tabular}


Table 2. Characterization of the métiers obtained from the classification of fishing operations based on the four categorical variables.

658

\begin{tabular}{l|l|l|l|l}
\multicolumn{1}{c}{\begin{tabular}{c}
\multicolumn{1}{c}{$\begin{array}{c}\text { Cluster/ } \\
\text { Métier }\end{array}$} \\
Sparids
\end{tabular}} & $\begin{array}{l}\text { Gear used } \\
\text { Gillnet } \\
\text { Gombined net }\end{array}$ & Autumn, Spring & $20-\leq 45 \mathrm{~m}$ & 380 \\
Guropean seabass & Gillnet & Autumn, Winter & $20-\leq 45 \mathrm{~m}$ & 153 \\
Mullet & Gillnet & Summer, Spring & $\leq 20 \mathrm{~m}$ & 287 \\
Hake & Gillnet & Summer & $>45 \mathrm{~m}$ & 324 \\
Fish soup & Trammel net & Summer & $\leq 20 \mathrm{~m}$ & 122 \\
$\begin{array}{l}\text { Rockfishes and } \\
\text { spiny lobster } \\
\text { Flatfishes }\end{array}$ & Trammel net & Summer, Spring & $20-\leq 45 \mathrm{~m}$ & 98 \\
\hline
\end{tabular}




\begin{tabular}{|c|c|c|c|c|c|c|c|c|c|c|}
\hline \multirow{4}{*}{$\begin{array}{l}\text { Cluster/ } \\
\text { Métier }\end{array}$} & & & & & & \multicolumn{2}{|c|}{ Fishing ground } & \multicolumn{2}{|c|}{ Net characteristics } & \multirow[b]{2}{*}{ Soak time (h) } \\
\hline & & & & & & Depth (m) & $\begin{array}{l}\text { Distance to the } \\
\text { shore (m) }\end{array}$ & $\begin{array}{l}\text { Mesh size } \\
(\mathrm{mm})\end{array}$ & $\begin{array}{l}\text { Height when } \\
\text { fishing (m) }\end{array}$ & \\
\hline & \multicolumn{2}{|c|}{ Target species } & \multicolumn{3}{|c|}{ Fishing period (month) } & Range & Range & Range & Range & Range \\
\hline & Main & Associated & J F M A M J & J A S O N D & Habitat & $($ mean $\pm s d)$ & $($ mean \pm sd $)$ & (mode) & $($ mean $\pm s d)$ & $($ mean \pm sd $)$ \\
\hline Sparids & Sparus aurata & $\begin{array}{l}\text { Dicentrarchus labrax } \\
\text { Other sparids }\end{array}$ & & & $P, R, S$ & $\begin{array}{l}5-60 \\
(23.3 \pm 7.4)\end{array}$ & $\begin{array}{l}10-2295 \\
(519.2 \pm 587.0)\end{array}$ & $\begin{array}{l}80-143 \\
(91-100)\end{array}$ & $\begin{array}{l}6-17 \\
(10.0 \pm 3.5)\end{array}$ & $\begin{array}{l}2-27 \\
(15.3 \pm 3.5)\end{array}$ \\
\hline $\begin{array}{l}\text { European } \\
\text { seabass }\end{array}$ & $\begin{array}{l}\text { Dicentrarchus } \\
\text { labrax }\end{array}$ & $\begin{array}{l}\text { Sparus aurata } \\
\text { Diplodus spp. }\end{array}$ & & & $\mathrm{P}, \mathrm{R}$ & $\begin{array}{l}6-60 \\
(22.4 \pm 7.8)\end{array}$ & $\begin{array}{l}10-2750 \\
(588.2 \pm 348.7)\end{array}$ & $\begin{array}{l}80-111 \\
(91-100)\end{array}$ & $\begin{array}{l}8-17 \\
(10.0 \pm 2.8)\end{array}$ & $\begin{array}{l}5-24 \\
(16.5 \pm 2.7)\end{array}$ \\
\hline Mullet & Mullus surmuletus & $\begin{array}{l}\text { M. barbatus } \\
\text { Scorpaena spp. }\end{array}$ & & & $\mathrm{P}, \mathrm{S}$ & $\begin{array}{l}3-50 \\
(16.8 \pm 11.4)\end{array}$ & $\begin{array}{l}10-2135 \\
(526.4 \pm 458.5)\end{array}$ & $\begin{array}{l}38-45 \\
(42-45)\end{array}$ & $\begin{array}{l}1-1.5 \\
(1.2 \pm 0.1)\end{array}$ & $\begin{array}{l}2-10 \\
(5.0 \pm 1.4)\end{array}$ \\
\hline Hake & $\begin{array}{l}\text { Merluccius } \\
\text { merluccius }\end{array}$ & Pagellus spp. & & & $\mathrm{S}$ & $\begin{array}{l}40-100 \\
(74.2 \pm 16.2)\end{array}$ & $\begin{array}{l}942-10868 \\
(4971.1 \pm 3091.9)\end{array}$ & $\begin{array}{l}63-91 \\
(71-77)\end{array}$ & $\begin{array}{l}3-4 \\
(3.5 \pm 0.4)\end{array}$ & $\begin{array}{l}2-24 \\
(14.5 \pm 3.4)\end{array}$ \\
\hline Fish soup & $\begin{array}{l}\text { Scorpaena spp. } \\
\text { Symphodus spp. }\end{array}$ & Mullus surmuletus & & & $\mathrm{P}$ & $\begin{array}{l}2-60 \\
(15.3 \pm 10.5)\end{array}$ & $\begin{array}{l}10-2659 \\
(368.8 \pm 461.3)\end{array}$ & $\begin{array}{l}42-71 \\
(42-63)\end{array}$ & $\begin{array}{l}1-2 \\
(1.5 \pm 0.3)\end{array}$ & $\begin{array}{l}3-23 \\
(7.0 \pm 4.7)\end{array}$ \\
\hline $\begin{array}{l}\text { Rockfishes and } \\
\text { spiny lobster }\end{array}$ & $\begin{array}{l}\text { Scorpaena scrofa } \\
\text { Palinurus elephas }\end{array}$ & $\begin{array}{l}\text { Labrus merula } \\
\text { Labrus viridis }\end{array}$ & & & R, S & $\begin{array}{l}5-87 \\
(34.7 \pm 19.5)\end{array}$ & $\begin{array}{l}10-5300 \\
(1679.1 \pm 1290.9)\end{array}$ & $\begin{array}{l}71-125 \\
(91)\end{array}$ & $\begin{array}{l}1-4 \\
(1.5 \pm 1.0)\end{array}$ & $\begin{array}{l}5-63 \\
(24.9 \pm 14.8)\end{array}$ \\
\hline Flatfishes & Solea solea & $\begin{array}{l}\text { Scophthalmus rhombus } \\
\text { Dicentrarchus labrax }\end{array}$ & & & S & $\begin{array}{l}10-90 \\
(66.2 \pm 5.5)\end{array}$ & $\begin{array}{l}177-11329 \\
(4008.7 \pm 1331.9)\end{array}$ & $\begin{array}{l}83-91 \\
(91)\end{array}$ & $\begin{array}{l}1-2 \\
(1.8 \pm 0.2)\end{array}$ & $\begin{array}{l}13-65 \\
(17.5 \pm 6.2)\end{array}$ \\
\hline
\end{tabular}

